\title{
Study Of The Mass Construction Of Al Irsyad Mosque In The Kota Baru Parahyangan
}

\author{
Andiyan, Firmansyah \\ Architecture Study Program Faculty of Science and Engineering, Universitas Faletehan \\ andiyanarch@gmail.com
}

Received: 13 August 2021; Revised: 02 October 2021; Accepted: 14 December 2021

DOI: http://dx.doi.org/10.37905/aksara.8.1.113-124.2022

\begin{abstract}
Al Irsyad Mosque is situated in Bandung, Indonesia, in Kota Baru Parahyangan, Padalarang. The construction of this mosque started on September 7, 2009, and was completed a year later. This mosque is modeled after the Kaaba in Makkah's Grand Mosque. This mosque was named one of the five finest buildings in the world in 2010 by the National Frame Building Association in the area of "religious architecture." This mosque is a work of modern architecture that succeeds in breaking the mold of most mosque shapes. Contemporary architecture is defined as a new, contemporary, distinctive, and original piece of architecture, regardless of its visual design, style, or theme. This course discusses descriptive qualitative research. This research is about modern architecture, as defined by many characteristics. The building's expression is subjective, contrasts with its surroundings, emphasizes a distinctive form, is out of the ordinary, and is appealing. The study's findings are anticipated to explain the use of modern architectural ideas at the Al Irsyad Mosque.
\end{abstract}

Keywords: Composition, Mass, Contemporary Architecture, Al-Irsyad Mosque, Expression

\section{INTRODUCTION}

Contemporary architecture did not develop overnight but was founded on the spirit of change engendered by England's Industrial Revolution. The Industrial Revolution led to the development of previously unknown architectural typologies, such as factory and warehouse typologies. Additionally, the industrial revolution revolutionized architecture by introducing new materials and methods. Contemporary architecture arose as a response to the demand for a new style. It then evolved into the art and craft period, when individuals became dissatisfied with manufacturing and organized social craft groups. Contemporary architecture continues into the creative eras of cubism, futurism, and neoplasticism. Contemporary architecture is rapidly evolving in response to global circumstances that no longer want to be bound by traditional principles (Ludwig Hilberseimer, 1964).

In addition to being a site of prayer for Muslims, the mosque is often utilized for a variety of other religious activities. The mosque's role is to organize Muslim holiday festivities, study the texts, provide social services and engage in other community activities. Mosque designs are becoming more varied, and each one is distinctive in its way. From ethnic to minimalist, classic to modern to current styles, there is something for everyone. Not only is the mosque pleasant, but its architecture is also very welldesigned, leaving anybody in awe of its splendor. This mosque was built by Ridwan Kamil, an architect and former mayor of Bandung, and is situated in Kota Baru Parahyangan, Padalarang, West Bandung Regency, West Java. The Kaaba inspired this cube-shaped structure in Mecca's Grand Mosque. The walls are likewise adorned with calligraphy; furthermore, there is a finely carved inscription "Lailahailallah." AlIrsyad Mosque, with a land area of about 1 hectare, has a capacity of around 1,500 
worshippers. Islamic architecture is an architectural work created from the concept of Islamic religious thought which must be sourced from the Al-Quran, Hadith, the Prophet's Sunnah, Fiqh Science and Muslim Scholars (Ulama)(Andiyan \& Aldyanto, 2021).

Al Irsyad MosqueThe mosque in Kota Baru Parahyangan is a contemporary structure without a dome; it is shaped like a basic cube. The mosque, which is situated in Bandung's Padalarang neighborhood, was inspired by Mecca's Kaaba. The mosque, primarily black and white, is modern, Islamic, and distinctive. The modern idea of Al Irsyad Mosque, Kota Baru Parahyangan, is evident in the building's architecture, which is very remarkable due to the mosque's distinctive design. The mosque's primary color is gray, which gives the structure a modern appearance, especially when combined with the arrangement of stones (concrete blocks) capable of forming threedimensional calligraphy for the phrase As-Shahadah. The mosque's peculiarity is evident in every aspect of its design, especially the main chamber, which lacks a pillar to support the ceiling, creating the illusion of a larger space. As with the mihrab design, there are no walls, allowing for direct views of the mountains inside the mosque. Natural sunlight is also felt in this mosque, owing to the many apertures. The pros and cons of the community against the health protocol rules that are applied have caused some regulations to be relaxed a little. To measure and educate public awareness in implementing health protocols, further research is needed(Cardiah et al., 2021).

This study aimed to ascertain the best practices for designing modern architecture at the Al Irsyad Mosque in Kota Baru, Parahyangan. It incorporates a novel idea into its construction. A concept still used sparingly in mosques in Indonesia.

\section{METHOD}

The term "assumptions" refers to fundamental assumptions made by researchers in a study. The following research makes the following assumptions: "Contemporary architectural planning at the Al Irsyad Mosque in Kota Baru Parahyangan."

A hypothesis (or, as some refer to it, a hypothesis) may be thought of as a tentative guess. The hypothesis is derived from the Greek words hypo, meaning underneath, and thesis, meaning establishment, supported view, and assurance. If the hypothesis is construed flexibly, it refers to a viewpoint whose veracity is still in question. To establish the veracity of an opinion, a hypothesis must be verified or established as accurate. A hypothesis may be formed based on the ideas mentioned before.

A descriptive hypothesis is a hypothesis or tentative solution to a defining issue with a single/independent variable. The Al Irsyad Mosque in Kota Baru Parahyangan has contemporary architecture.

Comparative hypotheses are conjectures or temporary solutions to the formulation of the issue that cast doubt on the comparison (comparison) of two study variables. Modern architecture has a distinctive and robust attraction when seen from outside the site inside the site, and vice versa, since the contemporary idea has an unusual architectural shape.

The associative hypothesis may be described as a preliminary response to a problem formulation that raises doubts about the connection (association) between two study 
variables. Al Irsyad Mosque in Kota Baru Parahyangan is a unique attraction due to its strategic position and is often utilized for prayer and festivals

This study was performed in the Al Irsyad Mosque in Kota Baru Parahyangan to examine the mosque's mass composition through the lens of modern architecture. The following data collecting procedures were used in this study on current architectural concepts:

\section{Data collection techniques}

As for specific data collecting methods, they are listed below:

A. Qualitative

Qualitative data collection is a method for locating materials that pertain to the subject of the study(Moleong, 2007)

\section{B. Quantitative}

Data collecting may take place in various situations and from a variety of sources in various methods to maximize outcomes(Lexy J. Moleong, 2000).

C. Observation

is a data collection method that is used in observation to acquire a variety of research data. There are three kinds of observation methods for data collection: participative, disguised, and unstructured.

1. Documentation

is a data-gathering method that utilizes a variety of non-human sources, including papers and synthetic materials.

2. Studying literature

The word "literary study" is also used to refer to a review of the literature, a theoretical study, a literature review, a literature review, and a theoretical review.

3. Data Collection Procedure

According to (Arikunto, 2000), data collection instruments are tools that are chosen and utilized by researchers to assist their data-gathering operations. Meanwhile, (Hajar, 1996) believes that an instrument is a tool for objectively obtaining quantitative information regarding changes in the properties of variables. Data Collection Procedure.

According to (Sumandi, 2008), a data-collecting instrument is a tool used to record - generally quantitatively - the state and activity of psychological characteristics. Technically, these psychological characteristics are divided into cognitive and noncognitive categories. Sumadi argues that stimulation is the determining factor for cognitive characteristics. In terms of non-cognitive characteristics, the stimulus is a declarative statement.

According to many of the expert views above, a research instrument is a tool used by researchers to gather quantitative data on the variables under study.

\section{The Research Stages}

The Al-Irsyad Mosque is a mosque in Padalarang, West Bandung Regency, West Java, Indonesia. The mosque began construction in 2009 and was finished in 2010. At first sight, the mosque resembles a large cube, similar to Saudi Arabia's Dome structure. This idea results in black lines running down the mosque's walls (Suhendar et al., 2020). 


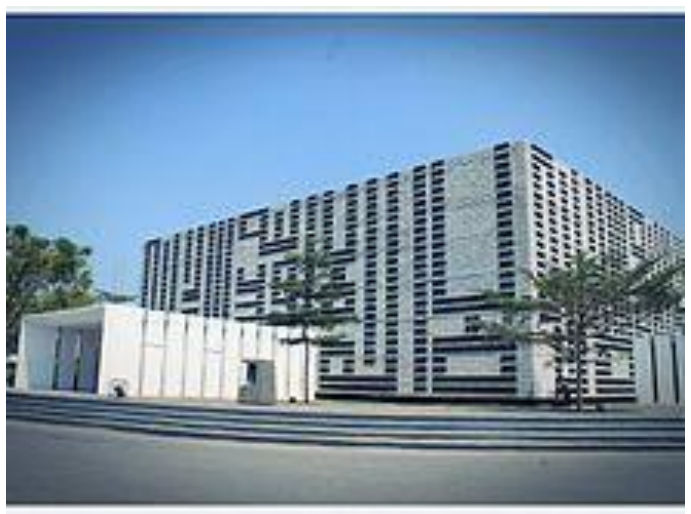

Figure1. This example shows the Al Irsyad Mosque, which is shown in this example. (Source: https://id.wikipedia.org/wiki/Masjid_Al-Irsyad)

\section{RESULTS AND DISCUSSION}

Al-Irsyad Mosque is a mosque in the Indonesian town of Padalarang, West Bandung Regency, West Java. The mosque began construction in 2009 and was finished in 2010. At first sight, the mosque resembles a giant cube, similar to Saudi Arabia's Dome structure. From the outside, this idea results in black lines running down the mosque's walls (SIREGAR, 2014).Al-Irsyad Mosque opened on 17 Ramadan 1431 Hijriah, or August 27, 2010. The structure is one-of-a-kind, magnificent, and strong. After just a few months of construction, the mosque's magnificent design was instantly recognized with a renowned world-class prize. The mosque is styled after the Kaaba. Gray serves as the foundation color. The placement of the bricks throughout the wall is very remarkable. The arrangement of the bricks forms the holes or gaps between solid bricks. Ridwan Kamil planned this mosque's construction. He came up with an innovative design for a mosque that makes use of natural light. The mosque's construction cost Rp 7 billion. The Qibla direction is designed to be exposed to the elements. At nightfall, the sun's rays will enter the mosque via the open front. This research is expected to be a reference for his research and can be developed again to a wider scale. Because research on cultural heritage buildings is still quite extensive and there are not many people who take this theme as the theme of their research(Andiyan \& Nurrisman, 2021).

When seen from afar, it will offer an Arabic pronunciation that reads as two monotheistic phrases, Laailaha Ilallah Muhammad Rasulullah, which means there is no deity. However, Allah and Muhammad are Allah's messenger. The Al-Irsyad Mosque's design is strengthened by using Arabic calligraphy text in the form of Kufi lettering. Two monotheistic phrases are linked to three sides of the structure through a brick arrangement intended as gigantic three-dimensional calligraphy. This mosque is 1,871 square meters and is painted in just three colors: white, black, and gray. The arrangement of these three hues enhances its beauty, modernity, simplicity while remaining elegant and pleasant to the eye.99 lights are placed throughout the mosque's interior to represent Allah's 99 names or Asmaul Husna. Each light, shaped like a box, has an inscription of Allah's name. The writing on the lights can be seen clearly from the mosque's front right side to the 99th inscription on the mosque's left side (Pertiwi, 2018). 
The mosque's prayer chamber has a capacity of about 1,500 worshippers. This mosque lacks pillars or pillars in the center to support the ceiling, giving it an airy aspect. The wall's four sides serve as a barrier and support for the roof (Nazhar, 2016). Due to the wind gaps on four sides of the mosque walls, the air circulation in the mosque chamber is excellent, and the space does not seem too hot despite the absence of air conditioning or a fan. In the priest's area, which is purposefully devoid of barriers, every creature praying will come face to face with God (Puspitorini et al., 2013). Landscape and open space, purposefully created in the shape of circular lines that encircle the mosque structure. The rings that round the mosque are modeled after the idea of tawaf, which encircles the Kaaba (Latifah \& Darmawan, 2021).

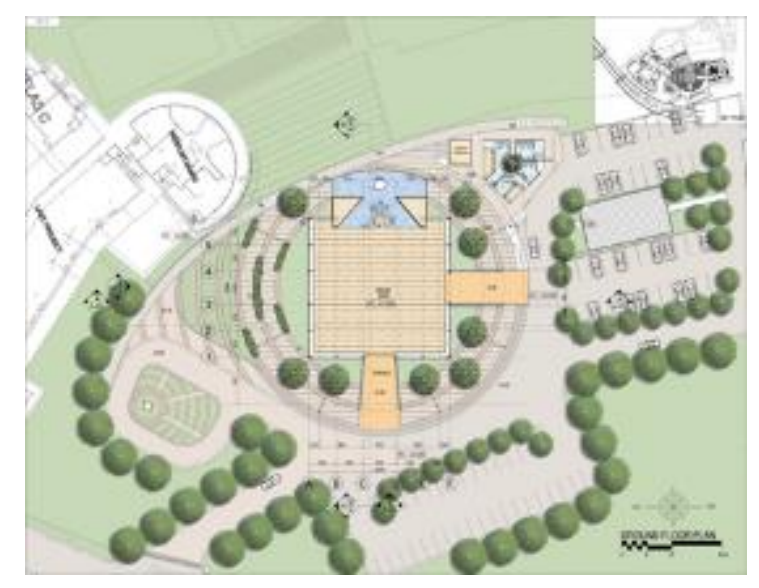

Figure 2. Ground floor plan.

(Source:https://www.archdaily.com/87587/al-irsyad-mosqueurbane/5012e86628ba0d06580004f2-al-irsyad-mosque-urbane-plan?next_project=no))

The Al Irsyad Mosque's layout is in the shape of a square with 48.47 x $28.5 \mathrm{~m}$ with details of the entry on the north and east sides. The circular region around this square design is the idea of tawaf, which refers to the territory surrounding the Kaaba.

1. The Mass Composition of Al Irsyad Mosque

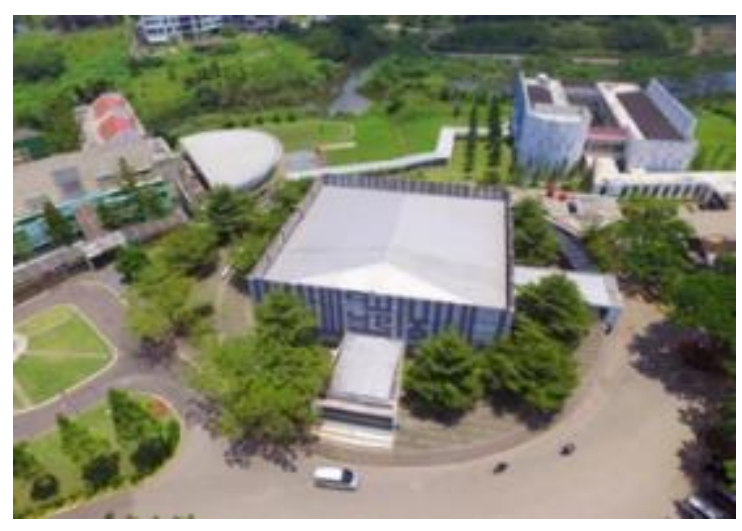

Figure 3. Mosque of Al Irsyad.

(Source: https://indonesia.tripcanvas.co/id/masjid-terindah/) 
The bulk of this mosque is shaped like a cube, with six identical square surfaces, each with two opposing sides forming a right angle. As a result of these dimensions, a cube is a static form that exhibits neither motion nor direction. Unless it is standing on one of the edges or corners, its shape is stable. Although the angular profile changes depending on the direction we gaze, the cube is an instantly recognized form.

(Edmund N. Bacon, 1974)The cube-shaped Al Irsyad Mosque was chosen since the mosque's primary idea was influenced by the shape of the Kaaba in Mecca. While the basic shape is a modern architectural idea, it has a solid religious and Islamic connotation. Additionally, the cube form improves the building's function, including the mosque's ability to expand due to the absence of supporting pillars in the main prayer area (Adiwirawan, 2017).

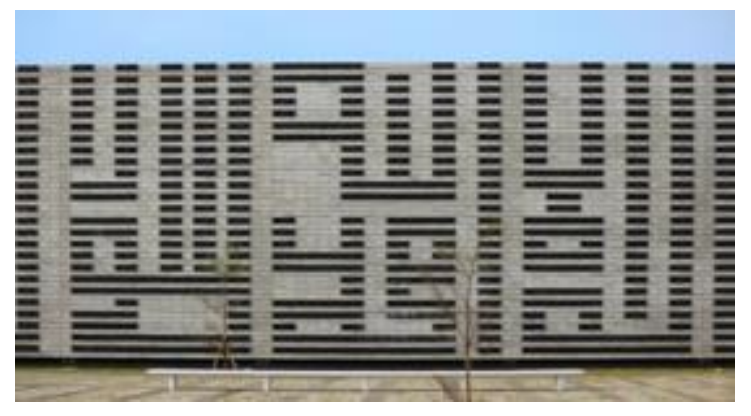

Figure 4. The Al-Irsyad mosque wall.

(Source: archdaily https://www.archdaily.com/87587/al-irsyad-mosqueurbane/5012e83c28ba0d06580004e9-al-irsyad-mosque-urbane-photo?next_project=no)

\section{Wall}

On the rectangular concrete block wall, According to Wikipedia, a rectangle is a shape made up of two pairs of parallel sides that are the same length and parallel to one another, and four right angles.

\section{Concrete Block}

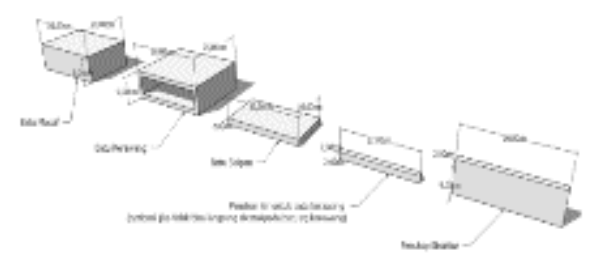

Figure 5. Concrete Block.

(Source: archdaily https://www.archdaily.com/87587/al-irsyad-mosqueurbane/5012e86228ba0d06580004f1-al-irsyad-mosque-urbane-sketch?next_project=no)

A concrete block or concrete molding stone is a structural component composed of portland cement or pozzolan, sand, water, and other additives, molded so that it

AKSARA: Jurnal Ilmu Pendidikan Nonformal 
satisfies the criteria and may be used as a wall cladding material. Additionally, this rule specifies a maximum water absorption value for bricks of $25 \%$.

The Al Irsyad Mosque's walls are concrete blocks and bricks that create giant calligraphy engraved with two verses from the creed. As a result, the calligraphy produces spaces that act as air vents, allowing the temperature within the mosque to seem cool even when there is no air conditioning or fans (Pawitro et al., 2014).

\section{Contemporary Architectural Concepts at Al Irsyad Mosque}

In addition to being a site of prayer for Muslims, the mosque is often utilized for a variety of other religious activities. The mosque's role is to organize Muslim holiday festivities, study the texts, provide social services and engage in other community activities. The mosque's design is becoming more varied, each with its individuality and beauty. From ethnic to minimalist, classic to modern to current styles, there is something for everyone. Not only is the mosque pleasant, but its architecture is also highly well-designed, leaving everyone in awe of its splendor. This is mirrored, for example, in Urbane's modern mosque architecture, Masjid Al Irsyad Kota Baru Parahyangan in West Bandung Regency (Riany et al., 2013).

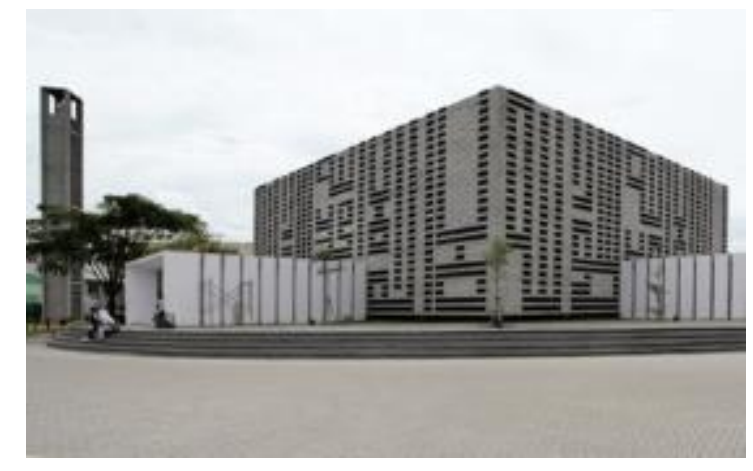

Figure 5. Mosque of Al Irsyad.

(Source: archdaily https://www.archdaily.com/87587/al-irsyad-mosque urbane/5012e84228ba0d06580004eb-al-irsyad-mosque-urbane-photo?next_project=no)

According to Urbane's collaborators, Reza A Nurtjahja, the bulk of Ridwan Kamil's mosque designs lacked domes. Ridwan Kamil's idea of a mosque without a dome alludes to the description of the mosques constructed during the Prophet Muhammad's lifetime. Indeed, according to tradition, the Prophet's Mosque in Medina is incorporated within the market and lacks a dome.

The Kaaba structure in Mecca's Al-Haram Mosque serves as the Baitullah and mecca for Muslims worldwide. It is shaped like a basic box. "Dome is a building construction method that has existed since Roman times," he said. "It allows for the creation of a pretty big building area without the need of pillars."

The lack of a dome is the first thing that will take your attention away from the mosque structure. Indeed, nearly all mosques in Indonesia have a distinctive dome on the roof. However, the architects have said that the dome does not have any cultural or 
religious significance. Thus, a dome is not required while constructing this Islamic house of worship.

\section{Natural Light}

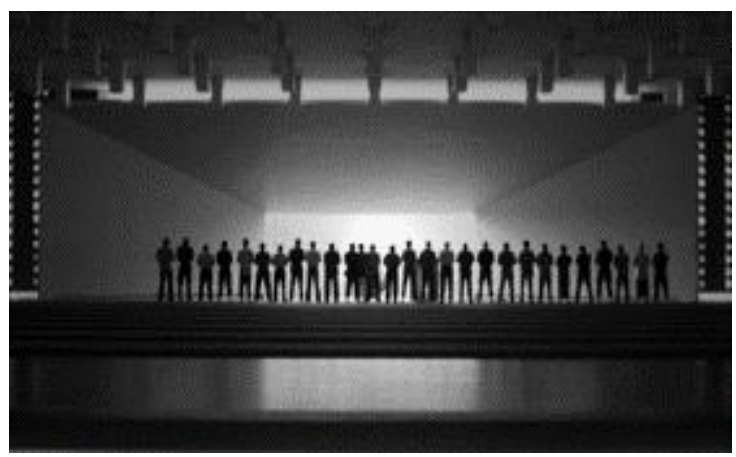

Figure 6. The interior of the Al-Irsyad Mosque.

(Source: archdaily https://www.archdaily.com/87587/al-irsyad-mosqueurbane/5012e83828ba0d06580004e8-al-irsyad-mosque-urbane-photo?next_project=no)

Natural lighting is created by a natural light source, mainly the sun, and changes according to the hours, seasons, and location. Sunlight is regarded as less effective than artificial lighting, owing to the sun's ability to maintain a consistent light level (Adinda, 2018).

Another distinguishing characteristic of modern design is the abundance of openings that allow natural light to enter the building or home. Contemporary design is associated with the use of expansive windows or skylights. The objective is to allow the maximum amount of sunshine to penetrate throughout the day.

\section{Material for the Outside}

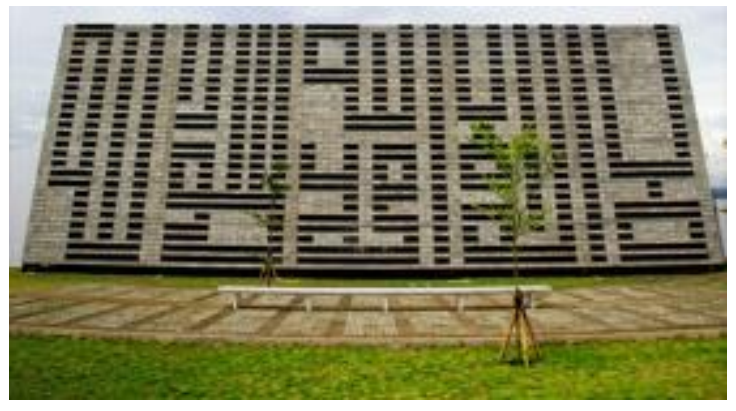

Figure 7. Facade of Al-Irsyad Mosque.

(Source:archdailyhttps://www.archdaily.com/87587/al-irsyad-mosqueurbane/5012e82b28ba0d06580004e5-al-irsyad-mosque-urbane-photo?next_project=no)

The exterior is the building is an outside shell. Another feature of modern architecture is the external material choices. The external material selection for a contemporary-style structure is often not restricted to a few materials. Designers or 
architects may use material exploration to generate dynamic forms and aesthetics while creating contemporary-style structures.

\section{Pay attention to the environment}

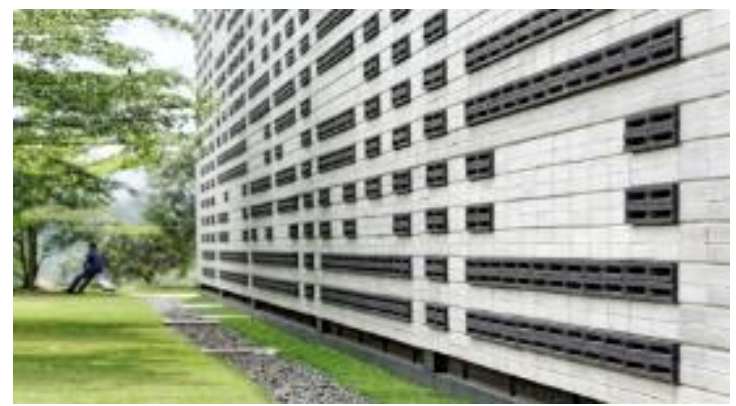

Figure 8. Al-Irsyad Mosque's roster wall.

(Source: archdaily https://divisare.com/projects/305413-pt-urbane-indonesia-m-ridwankamil-fernando-gomulya-al-irsyad-mosque)

The mosque, which seats 1,000 people, is likewise intended to blend in with nature. Natural ventilation is provided by the piled stone material, eliminating the need for extra air conditioning. Summer temperatures surrounding the mosque will seem more fantastic due to the mosque's proximity to water. Everyone within the mosque has the opportunity to gaze out through the lattice on the wall and take in the natural landscape.

Eco housing is a term that often appears in modern architecture. Numerous traditional structures include environmentally friendly and energy-efficient features. The contemporary design strives to blend the home into its natural surroundings when it comes to residential buildings. The objective is to protect the surroundings from disturbance and give the home a unique personality.

The Al Irsyad Mosque in Kota Baru Parahyangan demonstrates that Islamic design may also evolve in contemporary times. The mosque's design may also serve as an inspiration.

The mosque chamber is kept cool by a simple design that allows for enough air circulation and a lack of ornamental furnishings - offering tranquillity for the people's earnest devotion. The quiet of the mosque chamber awakens a sense of closeness to the Creator.

\section{CONCLUSION}

In my view, among the many ideas available in architecture, I am more interested in creating modern concepts since they allow for more creative innovation via the use of materials or construction materials that are fashionable or popular in recent years. The modern idea encourages us to give birth to and consider a new design that has never been before to create something distinctive and distinct from the surrounding surroundings, such as the Al Irsyad Mosque building in Kota Baru Parahyangan. Contemporary ideas may also adapt to their immediate surroundings, such as the natural conditions, evolving customs, etc. Thus, this does not imply that the modern idea is a "free" notion; instead, the contemporary concept contains laws that demand a game of harmony between colors, material, and form. Thus, despite its "awkward" and even 
irregular shape, with this modern idea, it may be transformed into something that is both attractive and harmonious, serving as a focal point for the region in which the building was constructed.

\section{REFERENCES}

Adiwirawan, E. (2017). Relasi Spasial Antara Kegiatan Ritual Ibadah Berjamaah Dengan Arsitektur Mesjid Di Bandung Studi Kasus: Masjid Cipaganti, Masjid Salman, Dan Masjid Al Irsyad. Idealog: Ide Dan Dialog Desain Indonesia, 2(1), $1-19$.

Andiyan, A., \& Aldyanto, I. (2021). Kajian Arsitektur Pada Massa Bangunan Masjid Cipaganti. Sang Pencerah: Jurnal Ilmiah Universitas Muhammadiyah Buton, 7(2), 189-199.

Andiyan, A., \& Nurrisman, O. (2021). Implementation of the New Function of the Sarinah Braga Building (Hotel De Braga By Artotel). Solid State Technology, 64(2), 5689-5695.

http://solidstatetechnology.us/index.php/JSST/article/view/10569

Arikunto, S. (2000). Pengelolaan Materiil. Primakarya.

Cardiah, T., Andiyan, A., \& Rahma, A. (2021). Implementation of Health Protocols at Mosques during the Covid-19 Pandemic in the city of Bukittinggi. Review Of International Geographical Education, 11(5), 3765-3771. https://doi.org/10.48047/rigeo.11.05.260

Edmund N. Bacon. (1974). Bentuk dan Wujud Dasar Dalam Arsitektur. Perancangan Kota.

Hajar, I. (1996). Dasar-dasar Metodologi Penelitian Kuantitatif Dalam Pendidikan. PT. Raja Grafindo Persada.

Latifah, I. S., \& Darmawan, C. (2021). Penerapan Ornamen Motif Kaligrafi Khuffi Pada Masjid Jami Al-Irsyad. DIVAGATRA-Jurnal Penelitian Mahasiswa Desain, 1(1), 61-69.

Lexy J. Moleong. (2000). Qualitative Research Methodology. PT Remaja posdakarya.

Ludwig Hilberseimer. (1964). Contemporary Architecture: Its Roots and Trends. Chicago, Il: PAul Theobald and Company.

Moleong, L. J. (2007). Qualitative Research Methodology. Gadjah Mada University Press.

Nazhar, R. D. (2016). Kajian Makna: Mihrab Masjid Kontemporer Al-Irysad Kota Baru Parahyangan. Serat Rupa Journal of Design, 1(2), 246-257.

Pawitro, U., Nitya, A., Septiandi, T., \& Hernomo, A. (2014). Kajian Ekspresi Ruang Luar dan Ruang Dalam pada Bangunan Masjid Al-Irsyad Kota Baru Parahyangan Ditinjau Dari Sustainable Design. Reka Karsa, 2(2).

Pertiwi, E. G. (2018). Kajian Sosiologi Masjid Al-Irsyad Parahyangan Bandung. Harmoni, 8(2), 1-11.

Puspitorini, H. D., Hardiman, G., \& Setyowati, E. (2013). Kenyamanan Thermal pada Masjid Al Irsyad Kotabaru Parahyangan, Jawa Barat. JURNAL ARSITEKTUR, $4(1)$.

Riany, M., Nugraha, D. P., Aneza, B., \& Iswandi, D. (2013). Penerapan Langgam Arsitektur Masjid Pada Bangunan Masjid Al-Irsyad Kota Baru Parahyangan. REKA KARSA, 1(1). 
SIREGAR, A. G. I. A. (2014). Menafakuri Akuntabilitas Masjid Al Irsyad Surabaya. UNIVERSITAS AIRLANGGA.

Sugiyono. (2012). Qualitative Quantitative Research Methods and R\&B. CV. Alfabeta.

Suhendar, R., Fatimah, T., \& Trisno, R. (2020). Kajian Bentuk Masjid Tanpa Kubah: Studi Kasus Masjid Al Irsyad Bandung. Arsitekta: Jurnal Arsitektur Dan Kota Berkelanjutan, 2(01 Mei), 19-31.

Sumandi, S. (2008). Metodologi penelitian/sumadi suryabrata. PT. Raja Grafindo Persada. 
AKSARA: Jurnal Ilmu Pendidikan Nonformal

P-ISSN 2407-8018 E-ISSN 2721-7310 DOI prefix 10.37905

Volume 08, (1), January 2022

http://ejurnal.pps.ung.ac.id/index.php/Aksara

124 AKSARA: Jurnal Ilmu Pendidikan Nonformal 